\title{
As representações jurídico-policiais sobre a prostituição na Cidade de Goiás (1850)
}

\author{
DANILO RABELO *
}

\begin{abstract}
RESUMO: Este artigo constitui parte da minha dissertação de mestrado "Os Excessos do corpo: a normatização dos comportamentos na Cidade de Goiás, 1822-1889” defendida junto ao Programa de Pós-Graduação em História da Universidade Federal de Goiás. Naquele trabalho, discuti a história da normalização dos comportamentos na Cidade de Goiás, durante o período imperial, tendo em vista a análise dos discursos médico, jurídico, moral e religioso incidindo sobre os espaços público e privado. O objetivo de tais discursos era a sujeição dos indivíduos às normas e padrões considerados mais racionais e eficientes, voltados para a maximização da produção de riquezas, do bem-estar físico, da saúde e do progresso. Ao longo da pesquisa foram analisadas as relações econômicas, sociais, políticas e culturais estabelecidas pela comunidade em confronto com as novas práticas discursivas que foram se inserindo ou sendo impostas.
\end{abstract}

PALAVRAS-CHAVE: Prostituição, normatização, discurso, prazer.

Este ensaio constitui parte da minha dissertação de mestrado "Os Excessos do corpo: a normatização dos comportamentos na Cidade de Goiás, 1822-1889” defendida junto ao Programa de Pós-Graduação em História da Universidade Federal de Goiás. Naquele trabalho, discuti a história da normalização dos comportamentos na Cidade de Goiás, durante o período imperial, tendo em vista a análise dos discursos médico, jurídico, moral e religioso incidindo sobre os espaços público e privado. O objetivo de tais discursos era a sujeição dos indivíduos às normas e padrões considerados mais racionais e eficientes, voltados para a maximização da produção de riquezas, do bemestar físico, da saúde e do progresso. Ao longo da pesquisa foram analisadas as relações econômicas, sociais, políticas e culturais estabelecidas pela comunidade em confronto com as novas práticas discursivas que foram se inserindo ou sendo impostas.

Na Cidade de Goiás, durante o século XIX, havia tentativas de um controle policial-sanitário por parte do Hospital São Pedro de Alcântara (único hospital de toda a Província de Goiás) e processos de crimes autuando comportamentos “irregulares” por parte de meretrizes, cuja insubmissão se perpetuava até o final do Império. A elaboração dos discursos normativos que tanto celebravam a família e os papéis sexuais dos indivíduos, bem como procuravam controlar a prostituição se fazia fora do âmbito jurídico, policial e médico, conforme podemos observar nas crônicas, poemas e cartas 
enviadas aos jornais daquela época. As representações elaboradas sobre a prostituição permitem não só o vislumbre da exploração social e sexual das mulheres dos estratos sociais subalternos, bem como as concepções de salubridade, moral, sexualidade, papéis sociais e sexuais que as sociedades elaboram ao longo do tempo. Por representações, Bordieu entende “atos de apreciação, conhecimento e reconhecimento e [que] constituem um campo onde os agentes sociais investem seus interesses e sua bagagem cultural. As representações objetais, expressas em coisas ou atos, são produto de estratégias de interesse e manipulação"1. Para Chartier "as representações são ao mesmo tempo matriz e efeito das práticas construtoras do mundo social”.2

O Código do Processo Criminal de 1832 que vigorou durante todo o Império não trazia referências explícitas à prostituição. A repressão sobre as prostitutas se fazia à medida que elas infringiam as posturas policiais que asseguravam a salubridade, a moral, os bons costumes e a tranqüilidade das famílias. Portanto, entre nós o Código de 1832 não cogitava do lenocínio, que só veio a ser incriminado pelo Código de 1890, nos seus artigos 277 e 278, posteriormente alterados pela chamada Lei Mello Franco (Lei no. 2992, de 25/09/1915), conseqüente ao compromisso assumido pelo Brasil na Conferência de Paris, de 1902, sobre o tráfico de mulheres.

Desde o início do Império, percebemos uma preocupação das autoridades governamentais em ordenar o espaço público urbano, retirando dele a aglomeração de elementos considerados perigosos pelas elites porque se recusavam a trabalhar sistematicamente. Esses elementos eram os camaradas, agregados, vadios, mendigos, imigrantes e as prostitutas. Contudo, a partir de 1850, quando o trabalho escravo passou a declinar em virtude do fim do tráfico negreiro, as autoridades policiais passaram a reprimir com mais vigor a presença desses elementos que promoviam "desordens” no espaço público, obrigando-os a “assinarem” termos de bem viver e a arranjar um trabalho regular.

\section{A LEGISLAÇÃo CONTRA A VADIAGEM}

Colocados à margem do sistema escravista, homens e mulheres pobres e livres vagavam entre as fazendas, cidades e arraiais, vivendo de "suas agências”, isto é, arrematando trabalhos esporádicos, como camaradas, operários das obras públicas, 
jagunços, cozinheiras, lavadeiras etc. Até mesmo os agregados, muitas vezes eram expulsos de seus lotes pelo fazendeiro e passavam a vagar até encontrar nova morada. Essa ocupação temporária era resultante do aviltamento que o trabalho manual representava numa sociedade escravista e levou as autoridades administrativas e os viajantes europeus, como Pohl e Saint-Hilaire, a elaborarem um discurso sobre sua indolência natural, desqualificando-os como vadios.

Para compelir as pessoas pobres e livres ao trabalho, eram instituídas não só as práticas normativas e disciplinares, mas também a repressão à força da lei e do policiamento ostensivo do espaço público, sobretudo a partir de 1850, quando por meio da Lei Eusébio de Queirós foi extinto o tráfico de escravos, dificultando a reposição da mão-de-obra escrava. A tabela abaixo nos mostra como a proporção do trabalho escravo foi diminuindo, na Cidade de Goiás, ao longo do século XIX:

\section{Proporção da População Escrava na Cidade de Goiás 1804-1872}

\begin{tabular}{|c|c|c|c|c|}
\hline Ano & População Livre & Escravos & População Total & \% de Escravos \\
\hline 1804 (a) & 4.992 & 4.432 & 9.424 & 47,0 \\
\hline 1832 (b) & 11.076 & 2.975 & 14.051 & 21,1 \\
\hline 1848 (b) & 13.478 & 2.096 & 15.524 & 13,5 \\
\hline 1872 (c) & 16.305 & 1.422 & 17.727 & 8,0 \\
\hline
\end{tabular}

Fontes: (a) J. E. Pohl, Viagem no interior do Brasil, p.141.

(b) ANRJ, Códice 808, volume I, folhe 96 e 117.

(c) Censo do Império do Brasil de 1872.

Frente a essa significativa queda na participação da mão-de-obra escrava no mercado de trabalho na Cidade de Goiás, fazia-se necessário, portanto, usar de todas as estratégias para que o trabalhador livre assumisse o seu papel como gerador de riquezas a serem apropriadas pelas camadas dominantes.

Conforme, afirmamos acima, o aviltamento que o trabalho manual representava para a população pobre e livre, levou as autoridades a identificar os trabalhadores esporádicos como vagabundos e vadios, portanto nocivos à ordem social. Assim, deviase procurar esvaziar o espaço público de tais elementos que perturbavam "a ordem, a tranqüilidade e a paz das famílias”. A legislação que trata da disciplinarização do espaço público, durante o período imperial, remonta ao título III da Lei de $1^{\circ}$ de outubro de 
1828 (Regimento das Câmaras) que, por sua vez, trata das posturas policiais. Encontramos no art. 66 as seguintes disposições a respeito do esvaziamento do espaço público dos elementos perturbadores da ordem e da moral:

Art. 66. Terão a seu cargo tudo quanto e diz respeito á polícia, e economia das povoações, e seus termos, pelo que tomarão deliberações, e proverão por suas posturas sobre os objectos seguintes:

$\S 3^{\circ}$ Sobre edifícios ruinosos, escavações, e precipios nas vizinhanças das povoações, mandando-lhes pôr divisas para advertir os que transitam; suspensão e lançamento de corpos, que possam prejudicar, ou enxovalhar aos viandantes; cautela contra o perigo proveniente da divagação de loucos, embriagados, animais ferozes, ou damnados, e daquelles, que correndo, podem incommodar os habitantes, providencias para acautelar, e atalhar os incendios.

$\S 4 .^{\circ}$ Sobre as vozerias nas ruas em horas de silencio, injurias e, obscenidades contra a moral publica. (grifo nosso).

O Código do Processo de 1832 e o Regulamento nº 120 de 1842, por sua vez, organizaram o policiamento do espaço público em círculos concêntricos. No município da Corte e nas capitais das Províncias ele estava a cargo dos Chefes de Polícia (art. 58); nos seus respectivos distritos, os delegados e subdelegados (art. 62) e juízes de paz (art. 65); nos seus respectivos quarteirões, os inspetores de quarteirão (art. 66), que deveriam observar as ordens e instruções que lhe seriam dadas pelos delegados e juízes de paz.

O policiamento do espaço público realizava-se, principalmente, à noite. As patrulhas rondavam pela cidade desde o cair da noite até o raiar do dia, dispersando os freqüentadores dos batuques e pagodes, prendendo os bêbados, os desordeiros, os escravos que saíam sem o bilhete de autorização de seus senhores após o toque de recolher, geralmente iniciado por volta das nove horas da noite.

As estatísticas do número de homens e mulheres presos por embriaguez, vadiagem, desordem, “para averiguações” entre outros, na Cidade de Goiás, durante o Império, são muito difíceis de serem levantadas. Em virtude de os registros policiais se acharem incompletos, os livros de entrada na Cadeia pública, existentes no Arquivo Histórico Estadual de Goiás (AHEG), se encontram parcialmente destruídos, impossibilitando o levantamento anual dessas prisões. Entre o mês de agosto de 1873 a fevereiro de 1874, foram presas vinte e uma pessoas para correção. O período de reclusão na cadeia variava de um a cinco dias de prisão. A variação do prazo de reclusão decorria tanto do comportamento do preso, da arbitrariedade das autoridades e do pagamento da carceragem. A carceragem consistia no pagamento ao carcereiro de 
uma taxa pela soltura de qualquer preso, mesmo que se tratasse da transferência para outro presídio. No caso dos infratores de posturas policiais ou presos recolhidos em custódia, a carceragem girava em torno de \$900 réis para as pessoas livres e $1 \$ 200$ réis para os escravos. A recusa em pagar a carceragem implicava em mais três dias de prisão. No caso dos escravos, estes só seriam libertados, quando fosse paga a referida carceragem $^{3}$.

A reincidência dos presos por desordem e vadiagem era bastante alta, obrigando os recalcitrantes a assinarem “termos de bem-viver”, conforme o Código do Processo de 1832 e o Regulamento $\mathrm{n}^{\mathrm{o}} 120$ de 31 de janeiro de 1842. Em determinados períodos, considerando o espaço de seis meses, os números poderiam apresentar-se maior ou menor. No período de janeiro a agosto de 1868, por exemplo, foram presas trinta e duas pessoas por esses motivos. A média anual, portanto, seria de quarenta e duas pessoas presas por ano, embora essas mesmas pessoas fossem presas várias vezes.

\section{A ELABORAÇÃO DA IDENTIDADE SOCIAL DA PROSTITUTA}

As mulheres pobres e livres que, desde os tempos coloniais, tinham maior mobilidade no espaço público e não se enquadravam no perfil da "santa mãezinha". Portanto, elas foram alvo da repressão policial, em virtude de seu comportamento considerado imoral e desordeiro. A maioria dessas mulheres era analfabeta, de cor parda ou negra e vivia do pequeno comércio, como quitandeiras, donas de tavernas, artesãs, costureiras e de suas "agências”, isto é, do trabalho esporádico como cartomantes, feiticeiras, parteiras, cozinheiras, lavadeiras, engomadeiras etc. A fim de completar suas rendas, muitas se entregavam à prostituição. Até mesmo aquelas que viviam amasiadas eram mal vistas à medida que a camada dominante, durante o século XIX, passava a regularizar suas relações conjugais por meio do casamento. As camadas populares continuaram a se amasiar, em virtude dos altos preços cobrados pelo clero sobre os emolumentos paroquiais.

Na sociedade escravista, as condições de sobrevivência para a população pobre e livre eram precárias e tornavam-se ainda mais difíceis para a população feminina que, em virtude dos preconceitos, limitava-se em desempenhar as ocupações acima mencionadas, todas profundamente depreciadas naquele período. Entretanto, nos 
processos por infração dos “termos de bem viver” contra várias prostitutas da Cidade de Goiás, sempre se recriminava o fato de nenhuma delas se ocuparem de um trabalho honesto:

Termo de bem viver que assigna Maria Rufina da Penha - Aos dezenove dias do mez de Maio do anno do Nascimento de Nosso Senhor Jezus Christo de mil oitocentos e oitenta, n'esta Cidade de Goyaz em a Secretaria de Policia, onde se achava prezente o Meretissimo Senhor Doutor Antonio Pereira de Abreu Junior, Chefe da Policia da Provincia, ahi compareceu Maria Rufina da Penha, prostituta, sem profissão honesta por onde possa subsistir, ébria pertubadora do socego público [...] (grifos nossos). ${ }^{4}$

A maioria das mulheres acusadas de serem prostitutas negava tal acusação, afirmando "viver de suas agências”. Essa constatação merece algumas considerações. Em primeiro lugar, conforme Laure Adler, “nenhuma se diz prostituta. Isso não é coisa que se diga nem como declaração de guerra nem como declaração de amor"5. O estigma e a marginalização social, afetiva e sexual levariam essas mulheres a negarem sua condição de prostituta, não obstante o depoimento das testemunhas de acusação. Em segundo lugar, para essas mulheres que viviam de trabalhos esporádicos, a prostituição era apenas mais uma entre suas várias ocupações. Por se entregarem à prostituição esporádica, poderiam não se considerar como tal, em comparação àquelas que viveriam exclusivamente do meretrício. Contudo, Laure Adler, citando Abraham Flexner, afirma “é prostituta toda a pessoa que habitual ou ocasionalmente tem relações sexuais mais ou menos banais mediante pagamento ou qualquer partida mercenária... Uma mulher pode ser uma prostituta mesmo quando não seja notória, nunca tenha sido presa e exerça simultaneamente uma outra ocupação remunerada"6. Por outro lado, reiteramos que essas mulheres provavelmente elaboravam suas identidades como trabalhadoras esporádicas e que, eventualmente, tinham que se prostituir para a sua subsistência ou negavam sua condição num expediente frustrado de escapar aos rigores da lei. Por último, o discurso das autoridades policiais e judiciárias revela a sua ambigüidade, pois se as ocupações de lavadeiras, cozinheiras, costureiras eram desqualificadas, em virtude de muitas escravas domésticas realizarem as mesmas funções, por outro lado elas eram valorizadas em detrimento do meretrício, bem como o trabalho esporádico e irregular.

O estigma parece definir toda a identidade das prostitutas. Assim, por meio de diferentes recursos as prostitutas estabeleciam limites à atividade profissional considerada fonte de estigma. A existência do “nome de guerra”, por exemplo, era na 
realidade um mecanismo de preservação do eu 7 . Deste modo, nas décadas finais do século XIX, Maria das Dores era conhecida por Maria Escolástica, Maria Luzia da Conceição tornou-se Maria Americana, Maria Gonçalves tornou-se Maria Cabeça. A lista de nomes prossegue, sendo alguns deles bastante pitorescos: Francisca Coriangu (Maria Sebastiana da Silva), Maria Eugênia “Doutora”, Maria Fortuna, Maria Paraguaya (Maria Andreaza da Costa), Maria Pritinha, Maria Tapuia (Maria Cardoso dos Santos), Maria Zarolha e assim por diante...

A despeito do discurso da medicina e da moral religiosa contra a figura da prostituta, considerada disseminadora de doenças físicas e morais, a prostituição se inseriu num esquema de utilidade sexual e social. Em virtude dos padrões e normas de comportamento baseados na valorização da virgindade da mulher, na monogamia, na sobrevivência do patriarcalismo, na maior liberdade sexual do homem, a prostituta exercia a função de aplacar os instintos genésicos dos homens, sobretudo dos jovens solteiros, dos celibatários, dos viúvos e dos esposos frustrados:

A reserva das antigas raparigas ingênuas, comumente condenadas a uniões desiguais, à influência refrigerante do confessor, à imagem castradora da mãe, a freqüente interrupção das relações sexuais devido à menstruação, à gravidez, ao aleitamento; a interrupção das relações sexuais com a menopausa, a amplitude das doenças ginecológicas, os imperativos da concepção constituem também estímulos a que se tome o caminho do bordel .

Portanto, a prostituta se tornava elemento de uma sexualidade utilitária, considerada um “mal necessário”. Tal representação remonta à Antigüidade Tardia, com Santo Agostinho que se referiu à prostituição nos seguintes termos:

Assim como o verdugo, por repugnante que seja, ocupa um posto necessário na sociedade, assim as prostitutas e seus similares, por mercenárias, vis e imundas que pareçam, são também necessárias e indispensáveis na ordem social. Retirai as prostitutas da vida humana e chegareis ao mundo da luxúria ${ }^{9}$.

Na Paris do século XIX, o Dr. Parent-Duchâtelet reafirmava essa matriz discursiva, escrevendo que "as prostitutas são tão inevitáveis num grande aglomerado de homens como os esgotos, os monturos, os depósitos de imundícies. A conduta da autoridade deve ser a mesma face àquelas e a estes”. ${ }^{10}$ Assim, no Rio de Janeiro, ao longo do século XIX, formou-se um debate entre os médicos favoráveis à sua extinção e 
aqueles favoráveis à sua normalização. Magali Engel ressaltou que nenhum dos dois projetos de controle chegaria a ser implantado tal como fora concebido, devido tanto às disputas e conflitos situados no próprio âmbito dos setores dominantes, mas também à resistência dos grupos e segmentos sociais aos quais de pretendia atingir, embora alguns dos aspectos que compunham o projeto médico de comportamento acabaram sendo efetivamente impostos ${ }^{11}$.

A prostituição também poderia representar para a mulher uma escolha, na medida em que poderia lhe proporcionar uma vida mais autônoma e independente. A prostituta tornava-se o paradigma de uma sexualidade insubmissa, uma personagem engajada na resistência à figura ideal da mulher frágil e submissa ${ }^{12}$. Os discursos normalizadores sobre a prostituição enfatizavam a oposição entre a prostituta e a mãe de família, chegando, às vezes, até em negar-lhe sua condição de mulher:

Prisões: A presente semana entre nós póde ser considerada a das prisões célebres [..] na noite de domingo 27, foram presas d'uma vez, dez mulheres perdidas (perdidas, bem se vê que não são mulheres) que brigavão a navalha por um modo desesperado (grifo nosso) ${ }^{13}$.

No entanto, a violência explícita e a arbitrariedade policial constituíam as formas de repressão predominantes, ainda que o Código Criminal de 1830 não considerasse a prostituição como um crime. Porém, o referido Código trazia uma diferenciação entre a mulher honesta e a mulher pública ao estabelecer as penas sobre o estupro:

Art. 222. Ter copula carnal por meio de violencia, ou ameaças, com qualquer mulher honesta.

Penas - de prisão por tres a doze annos, e de dotar a offendida.

Se a violentada fôr prostituta.

Penas - de prisão por um mez a dous annos ${ }^{14}$.

Enquanto o Código Criminal não legislava sobre a prostituição, o Código do Processo Criminal de 1832 inseriu as prostitutas no mundo da desordem:

Art. 12. Aos Juizes de Paz compete:

$\S$ Obrigar a assignar termo de bem viver aos vadios, bebados por habito, prostitutas, que pertubam o socego publico, aos turbulentos, que por palavras, ou acções offendem os bons costumes, a tranquillidade publica, e a paz das famílias ${ }^{15}$ (grifos nossos). 
O Regulamento n. 120 de 31 de janeiro de 1842, reformando o Código do Processo Criminal, trazia uma novidade na competência dos juízes de paz:

Art. 65. As attribuições policiaes dos Juizes de Paz consistem:

$4^{\circ}$ Em corrigir os bebados, por vicios, turbulentos,e meretrizes escandalosas, que perturbão o socego publico, obrigando-os a assignar termo de bem viver, com comminação de pena, e vigiando o seu procedimento ulterior ${ }^{16}$ (grifos nossos).

A novidade consistia, portanto, na preocupação da eficácia ou não da punição, expressa na recomendação de vigilância sobre as pessoas obrigadas a assinar o termo de bem viver. A cominação da pena, segundo o artigo 280 do Código Criminal consistia em “prisão de dez a quarenta dias; e multa correspondente á metade do tempo” 17.

Na Cidade de Goiás, na década de 1880, a lavadeira Maria das Dores, conhecida por Maria Escolástica e considerada prostituta de procedimento irregular, foi presa duas vezes por infração de termo de bem viver. Como a maioria das prostitutas era analfabeta, as assinaturas eram feitas por algum conhecido, geralmente do sexo masculino. O termo de bem viver de Maria Escolástica foi “assinado a seu rogo” em 23 de outubro de 1882, sendo que ela já havia sido presa por embriaguez em 08 de janeiro de 1881, em companhia de Maria Borba. Em 1883, Maria Escolastica foi presa por “embriagar-se diariamente, promovendo desordem procedendo a actos immoraes e d'esta sorte pertubando a paz de toda a vizanhança sua e a moral publica”. 18 Por essa contravenção, ela foi condenada a trinta dias de prisão e comutada a multa de trinta mil reis em dez dias de prisão em conformidade com o artigo 291 do Código de Processo. Contudo, ela foi presa em 04 de julho daquele ano e libertada sete dias depois. No processo do ano seguinte, Maria Escolástica, mais uma vez quebrou o termo de bem viver por crime de injúria contra Luiz José de França. O Código Criminal do Império assim legislava sobre esse crime:

Art. 236. Julgar-se-há crime de injuria:

$1^{\circ} \mathrm{Na}$ imputação de um facto criminoso não comprehendido no artigo duzentos e vinte e nove.

$2^{\circ} \mathrm{Na}$ imputação de vicios ou defeitos, que possam expôr ao odio, ou desprezo publico.

$3^{\circ} \mathrm{Na}$ imputação vaga de crimes, ou vicios sem factos especificados.

$4^{\circ}$ Em tudo o que póde prejudicar a reputação de alguem.

$5^{\circ}$ Em discursos, gestos, ou signaes reputados insultantes na opinião publica.

Art. 237. O crime de injuria commettido por algum dos meios mencionados no artigo duzentos e trinta. [...] 
$3^{\circ}$ Contra pessoas particulares, ou empregados publicos, sem ser em razão de seu officio.

Penas - de prisão por dous a seis mezes, e de multa correspondente á metade do tempo ${ }^{19}$.

A acusação de injúria cometida por Maria Escolástica, segundo o depoimento do injuriado e das testemunhas, baseava-se no fato de ela dizer que a mulher de Luís de França teria parido um "poldrinho”. O motivo de tal injúria foi o queixoso ter cobrado uma dívida da indiciada e, segundo uma das testemunhas, ela "respondeu julgar-se quites uma vez que por causa d'elle França já fora a Cadea e por causa d'essa divida já ter sido espancada [...]."20 Maria Escolastica, naquela ocasião, vingava-se de Luís de França por ter ele testemunhado contra ela no processo que a obrigou a "assinar" o termo de bem viver dois anos antes. Ela, porém, foi sentenciada em trinta dias de prisão e pagamento de multa de trinta mil réis, menos pelo crime de injúria que pela infração do termo de bem viver. Recolhida à prisão em 24 de fevereiro, foi posta em liberdade em 13 de abril, cumprindo ali cinqüenta dias de pena. Trinta deles, correspondentes à pena propriamente dita e o restante correspondente à multa arbitrada que não teve meios de pagar.

Tal como Maria Escolástica, a prostituta Maria Rufina da Penha, filha do Tenente Ramiro Dias de Corumbá e residente na Travessa da Alegria, também foi indiciada por infração de termo de bem viver “assinado” em 19 de maio de 1880, o qual, foi transcrito acima. Além de ser identificada como prostituta, sem profissão honesta, ébria, perturbadora do sossego público, ela também era acusada de viver “concitando dezordens e offendendo a moral publica com palavras obsenas e gestos considerados na opinião publica offensivos aos bons costumes. ${ }^{21}$ Os documentos policiais que tratam da prisão de Maria Rufina, naquela ocasião, nos informam sobre os gestos que eram considerados ofensivos à moral pública. De acordo com o relatório policial, Maria Rufina estava “pondo-se em estado de nudez indecente” e “colocando-se até em posição

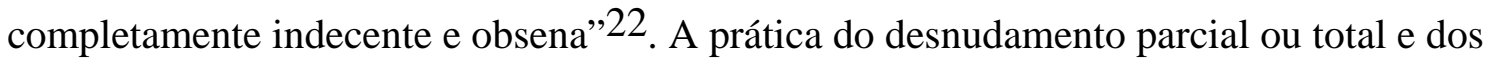
gestos lascivos é recorrente na prática da prostituição. Na cidade de Paris, durante o século XIX, por exemplo, havia o mesmo comportamento:

Lá pelas onze horas da noite, a coisa assanha-se: agastadas pela má sorte, tornam-se mais insistentes e baixam os preços. Vale tudo para não "voltar de mãos vazias": procurar os últimos lugares iluminados, fazer esperas à saída dos teatros, perseguir os 
clientes retardatários, desnudar-se um pouco mais, voltar a entrar nos cafés, embriagarse, correr de mesa em mesa, sentar-se nos joelhos dos cavalheiros, afagar-lhes o bigode... fechar o negócio ${ }^{23}$.

Em 1885, Maria Rufina foi indiciada por infração de termo de bem viver, ao ser acusada de ofender a três mulheres pobres com injúrias. Uma delas, Antonia Thomé, era vizinha da prostituta, cuja casa se limitava pelo fundo com a de Maria Rufina, “a qual não a deixa chegar ao terreiro sem que lhe atiri algum projectil, como por exemplo osso; ou faz algum soldado, que por ventura esteja em sua caza aproximar-se da taipa para devaçar o terreiro ou dirigir graçolas a mesma viúva”. No referido processo uma das testemunhas, Hygino da Costa Nunes, oficial do Exército, afirmou conhecer a querelada há mais de dez anos e que ela havia cumprido sentença de seis anos. No cumprimento de sua sentença, segundo esse depoimento, Maria Rufina foi transferida seguidamente da Cadeia de Leopoldina, para o presídio de Santa Maria, dali para Jurupensem e finalmente, para a Cadeia da Cidade de Goiás, onde cumpriu sua pena. O motivo de suas transferências era porque não podiam suportá-la naqueles cárceres. A prostituta limitou-se em dizer em sua defesa que o motivo de sua prisão foi que "a complicarão n’um roubo que se deu em uma caza cuja chave estava em sua mão”. 24

O Capitão Beraldo José de Araújo, de 58 anos, casado e empregado da Província aposentado (antigo amanuense da Secretaria de Polícia), quase sempre era chamado como testemunha de acusação nos processos contra prostitutas por infração de termo de bem viver. No processo contra Maria Rufina, ele foi ouvido como testemunha de defesa, declarando o seguinte:

\footnotetext{
durante todo o tempo que mora proximo a sua caza a querellada, tempo que pode regular a anno e meio, ainda não teve occasião de observar mao comportamento da querellada; quando entretanto o mesmo não pode dizer das declarantes.

E tanto é verdade o que diz que concente a querellada ter relações com sua caza; ser sua lavadeira e comprar-lhe por mais d'uma vez sabão e azeite feito pela mesma. 25
}

Além do Capitão Beraldo, foram ouvidas ainda duas testemunhas de defesa. O resultado é que a sentença do Juiz e Chefe de Polícia absolveu Maria Rufina da acusação. O exame desse processo nos leva a observar redes discursivas que desqualificavam e estigmatizavam as prostitutas. No testemunho de acusação, foi levantado o passado de ladra da prostituta indiciada, tentando provar sua índole desordeira, com o argumento de que nem nos presídios puderam suportá-la. Tal discurso 
via prostituição como um estado e não uma ocupação. Este discurso aproxima-se das idéias de certos romancistas que pensam que a prostituição é um destino; ou uma tara hereditária, como sustentam alguns criminologistas 26 .

Por outro lado, o testemunho de defesa reconheceu que a afamada prostituta ocupava-se de outros afazeres honestos (lavadeira e fabricante de sabão e azeite), mas em nome da moral, disse que consentia que ela tivesse relações com a sua casa. Ora, perante o Juiz a testemunha implicitamente declarou que, caso Maria Rufina tivesse comportamento considerado irregular, ele, Capitão Beraldo, não consentiria que ela tivesse relações com sua casa. O fato é que o mesmo Capitão Beraldo depôs como testemunha de acusação contra Maria Rufina, por ocasião da sua “assinatura” de Termo de Bem Viver, em 1880. Além disso, Maria Rufina continuaria a ser presa por desordem e embriaguez até 1892, quando se encerram os registros sobre ela. Não se trata aqui de conjecturar se o Capitão e as demais testemunhas de defesa mentiram ou não ao Juiz, pois eles alegaram que ela não ofendia às declarantes, pelo contrário, Maria Rufina era a ofendida e que ela não promovia ajuntamentos de soldados em sua casa. Porém, eles omitiram sobre o que ela fazia pelas ruas, sendo que os registros de suas prisões por desordem remontam a 1876. O que nos interessa aqui é que o testemunho do Capitão Beraldo entrou em contradição com o seu próprio testemunho de cinco anos antes, ao alegar que a prostituta não possuía nenhuma ocupação honesta e era desordeira.

O que podemos constatar é que no discurso de acusação negava-se à prostituta o reconhecimento de qualquer outra atividade ocupacional considerada honesta. O estigma de meretriz recobria sua identidade, negando-lhe qualquer outro papel social. Quando nos deparamos com os processos de Assinatura de Termo de Bem Viver quase não encontramos testemunhas de defesa, uma vez que a obrigação de assiná-los se fazia quando o indiciado era preso ou levado pelo inspetor de quarteirão ao delegado ou Chefe de Polícia por provocar desordem.

\section{CÓDIGOS DO SERTÃO: A VIOLÊNCIA JUSTIFICADA}

As brigas entre as mulheres das camadas populares fossem elas prostitutas ou não, acabavam muitas vezes em ofensas físicas, tentativas de assassinato e, não raro na consumação do homicídio. Na instauração dos processos criminais, ouvidos os 
depoimentos, estabelecia-se que os motivos que levavam às tentativas de homicídio eram sempre "banais". Esses motivos giravam, quase sempre, em torno de disputas amorosas ou questões de honra.

As freqüentes absolvições dos crimes de tentativa de homicídio sempre dependiam do júri, levando o Chefe de polícia, Evaristo de Araújo Cintra, a afirmar, em 1866, que

O temor da sancção penal esse poderoso auxiliar da justiça criminal que embarga 0 passo dáquelle ao encetar a carreira do crime, não é contido pela voz de sua consciencia, é muito fraco e impotente pela mímia indulgencia dos tribunaes particularmente do Jury, por que infelizmente o jurado entre nós não sabe compenetrar-se da sua elevada missão; nem sempre é a razão quem o guia nas suas decisões, de sorte que não poucas vezes é o seu coração quem o guia nas suas decisões, de sorte que não é raro ver-se absolvido um criminoso, cuja familia soube excitar a compaixão, ou mover qualquer outro affecto semelhante do jurado. 27

O código do sertão, segundo Maria Sylvia de Carvalho Franco, diferia do código jurídico das autoridades que adotava uma ampla rede de normas e ações racionalmente estruturadas. As testemunhas, em seus depoimentos, quando se pronunciavam sujeitas à polícia e ao aparelho judiciário, que objetivavam garantir a implantação dos preceitos racionais, não poderiam deixar de reconhecer esses preceitos. Por outro lado, muitas dessas testemunhas não deixavam de justificar a violência cometida. No código do sertão, a injúria e o ultraje não poderiam ser tolerados pacificamente; assim, virtude, destemor e violência não se excluíam, mas se confundiam numa gama variada de matizes. A violência, integrada à cultura no nível de regulamentação normativa, pode ser observada ainda na atitude de aceitação das situações antagônicas, como se fosse parte da ordem natural das coisas. "Contra esse estado de coisas ergueram-se juízes e promotores, não raro de origem urbana, desvinculados dos ambientes onde exerciam suas funções, alheios à moralidade ali vigente”28. Além disso, os jurados possuíam uma ignorância inadvertida para utilizar com propriedade os instrumentos de sua administração facilitando a absolvição dos réus, para descontentamento dos juízes e promotores. Em 1870, Maria Sebastiana da Silva, conhecida por Francisca Coriangu ameaçou espancar a Rumana Francisca dos Santos, pelo motivo de ter, a referida Rumana, falado mal dela. Diante da fúria de Francisca Coriangu, ambas foram obrigadas a "assinar" termo de bem viver 29. 
No mesmo ano de 1870, Maria Cardoso dos Santos ou "Maria Tapuia”, também lavadeira e prostituta, feriu, por ciúmes, com um canivete o seu amante, o alferes Adão Rodrigues Vidigal. No inquérito, os depoimentos das testemunhas levam a um drama semelhante ao romance Carmen de Mérimée, só que às avessas, isto é, neste caso a mulher é que foi abandonada por outra e tentou matar seu amante. Adão Vidigal tinha relações consideradas ilícitas com Maria Tapuia, mas passou a procurar os carinhos de Dionísia dos Santos. Por sua vez, Dionísia parecia estar interessada em Manoel Sabino e se esquivava das atenções de Adão, alegando sempre estar doente. Na ocasião do crime, Adão encontrava-se na casa de Dionísia, quando a acusada chegou e começou a brigar com seu amante, ferindo-lhe gravemente abaixo da costela e em uma das pernas. Em seu depoimento, Maria Tapuia disse que

na noite em que se diz aconteceo o crime ella interrogada bebeo muita caxaça, depois não sabe o que se passou; que tinha relações ilícitas com Adão Vidigal, que o mesmo queria bem, como ainda quer, portanto, não podia ser de sua intensão fazer mal ao mesmo; que no estado de embriaguez em que se achava ella interrogada, podia ter commettido desatinos, de nada porem, tem consciencia e assim não pode affirmar ou negar que ferisse a Adão Vidigal; que a testemunha Dionizia dos Santos é sua inimiga por a mesma pretender a amizade de Adão Vidigal, e este dar preferencia a ella interrogada. 30

No processo, nem a vítima e nenhuma das testemunhas referiram-se ao fato de Maria Tapuia se encontrar embriagada na hora do crime. Uma das testemunhas a ouviu dizer logo após o crime: "morreu danado, prometti mas não faltei”, sugerindo uma possível premeditação, afinal outra testemunha declarou que Adão Vidigal teria cortado Maria Tapuia por ciúmes, dois meses antes. Mas, o fato é que a ré foi absolvida pelo júri, pois existia a favor dela "a circunstância attenuante de $§ 9 .^{\circ}$ do art. 18 do Codigo Criminal - a ré cometteo o crime no estado de embriaguez [...] A ré cometteo o facto criminoso sem má fé, isto é, sem conhecimento do mal e intenção de o praticar”. 31 Igualmente, em 1884, a lavadeira e prostituta Maria Luzia da Conceição, denominada "Maria Americana”, fez ferimentos graves em sua companheira de residência Raymunda Maria da Conceição, conhecida por "Piranha”. Segundo os autos do processo, a ofensa física ocorreu pelo fútil pretexto de corrigi-la por se achar embriagada. Também ela foi absolvida pelas mesmas circunstâncias atenuantes que relatamos anteriormente, sendo que muitas das testemunhas referiram-se ao hábito da cachaça de ambas as prostitutas. 32 


\section{A RUA, A TAVERNA, O BATUQUE E O “BORDEL”: ESPAÇOS DE LAZER E DESORDEM}

Se o vício da embriaguez era condenado como causa de desordens e ofensas à moral pública por parte de homens considerados vadios e bêbados por hábito, bem como por mulheres consideradas meretrizes, a condição de embriaguez servia como atenuante nos processos contra os crimes de ofensas corporais, tentativa de homicídio e homicídio consumado. A absolvição dos crimes frente às circunstâncias atenuantes da embriaguez retirava a responsabilidade do infrator perante a Justiça, portanto, a prisão correcional por desordens causadas por embriaguez possuía um caráter preventivo de coibir tais excessos, garantindo a paz e o sossego das famílias.

Deste modo, a vigilância da Lei recaía sobre as tavernas, estabelecimentos que ofereciam o suprimento de aguardente à população, bem como lugar de reunião de camaradas, desocupados, soldados, prostitutas e escravos, enfim, os indivíduos enquadrados como a escória da sociedade.

Em 1883, encontramos Maria Tapuia, transformada em uma senhora casada, vendendo aguardente e quitandas em sua casa. Segundo o Alferes Antônio Marques, ela era auxiliada por Ignacia Eduvirges, Senhoria Francisca de Jesus e Maria Benedicta, e "por faserem actos immorais publicamente e hostilizarem familias honestas e por conseguinte cooperão para os freqüentes motins e desordens”. $33 \mathrm{Na}$ delegacia, compareceram todas as indiciadas com exceção de Maria Benedicta que, talvez por estar ausente, foi a única a ser acusada pelas testemunhas como "vagabunda, prostituta, bêbada, parecendo até idiota.” Apesar dos testemunhos favoráveis, todas foram obrigadas a "assinar” termo de bem viver. No mesmo sentido, em 1896, o Capitão Luiz de Macedo solicitava ao Intendente Municipal, o fechamento de uma taverna localizada em frente ao quartel que dispersava as praças de suas obrigações.

Além da estreita vigilância policial, para os donos destes estabelecimentos, era difícil mantê-los devido à alta tributação que as autoridades provinciais impunham. Eles deveriam pagar o imposto da Décima Urbana de seu Prédio e a taxa de 6\$000 réis sobre as tavernas. Muitos dos taverneiros requeriam à Tesouraria Provincial a isenção de tais impostos, alegando pouco capital empregado, não chegando a $30 \$ 000$ réis. As 
autoridades fiscais indeferiam tais requerimentos, pois se o fizesse eliminaria uma das principais fontes de arrecadação do erário público.

Espaços por excelência da sociabilidade, as tavernas constituíam lugares onde as pessoas afluíam para conversar, saber das novidades, divertir-se. Elas eram o local onde as relações sociais exerciam-se sob a atração e repulsão entre os indivíduos e o espaço das libações, dos festejos e da violência. Sobre os bares, Mafesoli escreveu que

quando num vilarejo ou num bairro um bar fecha as suas portas, é um pouco de vida que cessa. No espaço humilde onde se exprimem tantas alegrias e desventuras, nesse espaço onde estão em jogo tantos afetos e conversações, a sólida trama social se constitui gradativamente. Não se trata de extrapolar mas, certamente, nesses espaços é que se vive a relação de alteridade em toda a sua pequeneza e em todo o seu trágico ${ }^{34}$.

O espaço público das ruas e das tavernas poderia representar um local ou espaço instável, de intenso movimento, conflitos, tentações, lutas e perigos, onde cada indivíduo confronta-se consigo mesmo e com os outros, é o "reino do cada um por si”, isto é, local de contradições ${ }^{35}$. Vimos que as patrulhas iniciavam sua ronda desde o toque de recolher até a madrugada. Andar pelas ruas e becos mal iluminados da Cidade de Goiás ${ }^{36}$ poderia constituir uma aventura perigosa, principalmente para as mulheres. No ano de 1872, às onze horas da noite chuvosa do dia 15 de fevereiro, Sophia Maria, costureira, de 20 anos, foi presa pela patrulha por se achar vestida de homem, coisa que era proibida pelas posturas policiais da cidade: “andar por lugares publicos em trajes desonestos, indecentes ou que não sejam do próprio sexo, salvo nesta parte em dias de carnaval ou mascarado com licença da polícia”. 37 Segundo seu depoimento, ela saiu vestida assim para comprar fumo na venda de Raymundo de tal, em companhia de Maria Francisca.

Enquanto a postura policial legislava sobre a moral e reservava os atributos característicos de cada sexo, o expediente de Sophia Maria revelava que a rua, durante a noite, não era um local adequado para as mulheres andarem desacompanhadas. Assim, ela se travestiu de homem para circular sem temores pelas ruas da cidade. Michelle Perrot afirmou que a Revolução Francesa acentuou a definição das esferas pública e privada, valorizou a família, diferenciou os papéis sexuais estabelecendo uma oposição entre homens políticos e mulheres domésticas ${ }^{38}$. A rua era, portanto o espaço dos 
homens, enquanto a casa era o espaço das mulheres. Somente mulheres de má fama, numa palavra, prostitutas, poderiam andar desacompanhadas pelas ruas à noite.

Assim, as ruas e, por extensão, o espaço urbano tende a ser considerado como o lugar por excelência da decadência. Mas essa questão possui, segundo Mafesoli, uma forte conotação moral ${ }^{39}$. A partir dessa idéia criou-se, desde tempos imemoriais, o contraponto de um meio rural, bucólico e paradisíaco como espaço privilegiado da interioridade do homem ${ }^{40}$. Por outro lado, Mafesoli considera que "por Cidade, entendemos esse desejo irreprimível de estar-junto [...] A cidade serve de substrato à socialidade em ato da vida cotidiana e, por ser resultado e causa da concretização dos encontros, ela é, segundo a expressão de J. Ladrière, o 'indutor existencial' por excelência"41.

Além das tavernas, as opções de lazer da população pobre e livre consistiam nas festas religiosas (novenas, quermesses, folias), passeios no campo (pescarias, banhos nos rios), visitas aos vizinhos, jogo e batuques e/ou pagodes. Tanto o jogo quanto o batuque eram proibidos por Lei, através das Posturas Policiais da Cidade. As primeiras posturas policiais do Município de Goiás foram promulgadas a 07 de fevereiro de 1831 e, conforme a necessidade foram sendo alteradas ao longo do império.

Os jogos, segundo as posturas do Acto n. ${ }^{\circ} 2893$ de 23 de junho de $1881^{42}$, dividiam-se em lícitos e ilícitos. Os lícitos eram os jogos carteados de cálculos e de exercícios físicos, como o voltarete ${ }^{43}$, solo ${ }^{44}$, dominó, xadrez, damas, bilhar, bodas etc. Os ilícitos eram os jogos de parar, de fortuna ou azar como bisquinet, trinta e um, vermelhinha 45 , pinta etc. Enquanto estes eram proibidos tanto no espaço público quanto no espaço privado, aqueles eram também proibidos no espaço público. Os jogos eram vedados aos menores e escravos e as multas variavam de 5 a $30 \$ 000$ réis por contravenções a essas posturas.

Os batuques e pagodes congregavam membros das camadas populares, civis ou paisanos, militares (soldados e oficiais) e escravos. Os ritmos dançados nestes bailes de fundo de quintal eram o cateretê, o lundu e o samba, todos de origem africana e que por suas coreografias sensuais eram imputados como danças estrepitosas e obscenas. As penas sobre os participantes de batuques eram prisão de cinco dias ou multa de $4 \$ 000$ réis para o dono da casa e $2 \$ 000$ réis para cada um dos participantes. As patrulhas que percorriam as ruas à noite, sempre apareciam para dissolver estes ajuntamentos 
considerados ilícitos. Os participantes, por sua vez, resistiam e, não raro, entravam em choque violento com os inspetores de quarteirão e/ou com os soldados da ronda policial.

Na noite de 14 de julho de 1883, às duas horas, o Cabo José Caetano Fellis encontrou um brinquedo com palmas, alta gritaria e até toque de tambor de tamborete na casa do Sr. Pedro Xavier que, advertido para não continuar, tratou de por o nome do cabo na entoação do cateretê e do samba para melhor o "xincalhar", prosseguindo assim até às quatro horas da manhã. O cabo se limitou a dar parte no Quartel da Companhia de Polícia, pedindo providências. 46 Contudo, a chegada da patrulha poderia acabar em grossa pancadaria e fuga desesperada dos participantes. Vejamos por exemplo que, na noite de 16 de abril de 1889, sob ordens do Chefe de Polícia, a patrulha ao dissolver o batuque em casa de Felisbina de tal, alegou que

foi necessário dar-se planchadas, no individuo Sebastião de tal que resistia á tal prizão, todavia não se notando vestigio algum de espancamento, procedendo das mesma maneira com o ex-praça Antonio Bibiano da Penha, que tentava assassinar a uma das praças da patrulha, e cuja faca junto a esta vai. Recolhi apenas a cadeia, 6 homens e 2 mulheres, porquanto as outras pessoas que fazião parte de tal orgia, se afujentarão à chegada da patrulha (grifo original) 47 .

A desqualificação dos batuques e de seus participantes fazia parte de um discurso atávico das camadas dominantes em desprezar as manifestações culturais populares considerando-as como ordinárias e vulgares, bem como no sentido de atuar na preservação da ordem e do direito ao silêncio nas altas horas da noite. O paradoxo do discurso da Ordem, segundo Foucault 48 , é que ele se define pelos discursos alternativos, que, no entanto precisam ser expulsos. É nesse sentido, que o saber, manifestando-se nas práticas discursivas e extradiscursivas exerce determinado poder na sociedade.

O hábito de banhar-se nos rios também era severamente criticado, inclusive pelos jornais da cidade. O suplemento do Correio Official $n^{\circ} 55$ de 19 de agosto de 1881, trazia o seguinte reclame:

Chamamos a attenção da illm. ${ }^{\mathrm{a}}$ camara municipal, e da policia sobre os costume de tomarem banhos no rio vermelho, da pedreira até o novo matadouro.

Ahi se encontram a toda hora homens e mulheres - as lavadeiras, completamente nus, quando tem-se tornado a margem do rio um passeio público visitado freqüentemente pelas familias. 
Para extinguir o costume não temos necessidade de postura especial; basta a fiel execução da disposição do art. 280 do codigo criminal, que diz assim:

"Praticar qualquer acção que na opinião pública seja considerada evidentemente offensiva da moral e bons costumes, sendo em logar publico

Penas de prisão por 10 a 40 dias e de multa correspondente á metade do tempo".

O local a que nos referimos, é mais que publico, e ahi ostentam-se completamente nu um filho ou filha de Adão e Eva - é praticar uma acção offensiva da moral e dos bons costumes.

Cumpre abrir fileiras e deixar passar a familia cercada do respeito e da consideração a que tem direito.

A familia é o pudor social; respeite-se-o.

Não podemos avaliar a participação do bordel nas formas de lazer da Cidade de Goiás, pelo menos o termo "bordel” ou "lupanar” não era utilizado pelas autoridades judiciárias e policiais. Afinal, naquela cidade não se constitui uma "região moral” ou zona de meretrício, tal como no município da Corte ou em Paris, à época de ParentDuchâtelet. As “casas de família” ficavam lado a lado com as casas das prostitutas. Nas ocorrências policiais, nos processos judiciários e nos jornais vilaboenses não há qualquer referência a prostitutas aquarteladas em bordéis. Todavia, nas denúncias contra comportamentos irregulares de prostitutas, havia sempre acusações de que as meretrizes recebiam soldados e paisanos em suas casas, com altas vozerias, palavras obscenas incomodando a paz e o sossego das famílias.

Na década de 1870, havia na cidade uma casa que abrigava diversas mulheres que se dedicavam ao meretrício. Era a alegre residência do Sr. José Joaquim de Moura, vulgo "José das Cordinhas” que, juntamente com sua mulher, permitia a prostituição de suas filhas: Helena, Maria Pedrosa, Henriqueta e Bernarda. A casa possuía fama de "ter sido a perdição de muitas môças e o coito de muitos escravos que alli se vão embriagar comettendo furtos de dinheiro e outros objectos para poderem ter bôa aceitação nessa nova caverna de Caco”. Das pessoas arroladas que ali freqüentavam constavam-se Flamina de Tal, os escravos do Brigadeiro João Nunes da Silva, uma escrava do cirurgião-mor Vicente Moretti Foggia e Egydio, escravo do Capitão Antônio Marques Fogaça. No processo de 1876 que as obrigou a "assinar” termo de bem viver, Maria Pedrosa, a única que compareceu à Delegacia de Polícia, confessou ser prostituta e beber aguardente, mas alegou que nunca perdeu o juízo e os barulhos e pancadas eram devidos aos castigos infligidos por sua própria mãe. Duas das testemunhas de acusação alegaram que as referidas prostitutas promoviam desordens tendo um padre de avançada idade sido espancado naquela residência. Apenas uma das testemunhas disse 
desconhecer que ali se promoviam desordens. ${ }^{49}$ Poder-se-ia dizer que a casa do Sr. José das Cordinhas estava organizada como o bordel da peça Os sete gatinhos de Nelson Rodrigues. Não só as suas próprias filhas entregavam-se ao meretrício, como para lá acorriam outras moças para exercer tal ofício. Porém, ocorre que nenhum dos atores sociais identificou aquela residência como um bordel.

Mais do que os distúrbios provocados na casa de Zé "Das Cordinhas" o que parecia incomodar às autoridades era a reunião de escravos ali recebidos. O escravo Egydio teria roubado 50\$000 réis do Inspetor Salustiano Jacintho d'Andrada Pessoa, indo dividir o fruto do seu roubo com os moradores daquela residência, conforme relatou o subdelegado Jozé Ignacio de Azevedo que recuperou parte do dinheiro.

Michel Mafesoli “afirmou que o espaço molda coercitivamente os hábitos e costumes do dia-a-dia que, por sua vez, permitem a estruturação comunitária [...] há um constante vaivém entre a cidade e a socialidade, na medida em que um bairro, suas ruas, travessas e becos estruturam a trama social de maneira bem precisa” 50 . No caso da Cidade de Goiás, a estrutura das casas geminadas, isto é, coladas umas às outras ou, no dizer daquela época, “fazendo parede e meia”, permitia que os vizinhos escutassem tudo o que se passava no interior das residências. A ausência de intimidade em relação à vizinhança teria amiúde motivado as constantes denúncias contra as vozerias e ditos considerados obscenos nas casas das prostitutas. Nem mesmo as tentativas de confinar as meretrizes em guetos ou zonas específicas, numa tentativa de controle à prostituição, produziram resultados satisfatórios, pois nos lugares em que isto aconteceu sempre havia a prostituição clandestina de mulheres insubmissas que não se dobravam às práticas e discursos normativos 51 .

\section{SOLDADOS E MERETRIZES: ENTRE A PAIXÃO E A VIOLÊNCIA}

Os laços de solidariedade entre as mulheres das camadas populares e os soldados eram muito fortes, especialmente entre eles e as prostitutas. A maioria amasiava-se entre si. 52 Muitas mulheres trabalhavam para estes soldados como lavadeiras, engomadeiras, cozinheiras etc., como o caso de Maria Alves que “tinha relações com soldado Fernando 
Justiniano Ferreira de quem era lavadeira”. No dia 14 de setembro de 1862, Maria Alves foi acusada de ajudar o seu amante a desertar do Batalhão de Caçadores. 53

Nos processos de infração dos “termos de bem viver” por mulheres acusadas de meretrício e procedimento considerado imoral e irregular, quase sempre era mencionado que em suas casa reuniam-se soldados. A 27 de janeiro de 1883, a Sr ${ }^{a}$ Ana Paz, "casada mas separada do marido”, foi acusada de embriagar-se freqüentemente, de ser prostituta e receber em sua casa soldados e paisanos que faziam grande barulho proferindo palavras obscenas. Ela contestou todas as acusações, alegando que "não se occupa é verdade, em serviço, fora de sua caza, mas trabalha em sua propria caza para soldados e outras pessoas”. Como era de se esperar, ela “assinou” o indefectível termo de bem viver. 54

Quanto às relações amorosas, é possível que os soldados agissem como proxenetas, cafetões ou gigolôs, mas os processos judiciários e boletins policiais não relatam isto. $\mathrm{O}$ fato de ter um amante fixo, não impedia essas mulheres de exercerem o ofício de prostituta. No caso de Maria Tapuia e do Alferes Adão Rodrigues Vidigal, havia ciúmes de ambas as partes, mas parece que, em geral, os amantes aceitavam a profissão de suas companheiras. Acreditamos que, o motivo de tal aparente aceitação era que aquelas mulheres não se casariam com seus amantes, o estigma de prostituta as condenava à condição de concubina. A referida Maria Tapuia foi o único caso que encontramos no qual a prostituta se casou, mas nem por isso ela deixou de ter um comportamento considerado irregular, especialmente quando seu marido estava em viagem. Além disso, os baixos soldos dos militares quase não os habilitavam a sustentar uma família. Assim, entre ser condenado a se tornar um celibatário e desfrutar dos favores constantes de uma concubina que, eventualmente também era meretriz, os soldados preferiam, não raro, a segunda opção.

Essa sociabilidade entre prostitutas e soldados levou o Dr. Corioloano Augusto de Loyola, delegado de polícia, em 1870, a escrever:

Cumpre-se communicar a V.S. que, durante a semana passada, não chegou ao meu conhecimento facto algum que alterasse a ordem e a tranquilidade publicas, salvos alguns insultos trocados entre prostitutas e soldados unicas classes que incommodão a policia nesta cidade ${ }^{55}$. 
Até o final da Guerra do Paraguai (1864-1870), a desqualificação dos soldados, sobretudo do exército, era recorrente entre as autoridades e as camadas dominantes. A criação da Guarda Nacional, durante o Período Regencial, demonstrou a desconfiança que as elites proprietárias tinham em relação aos soldados que vinham dos estratos mais baixos da população livre. A fim de conter a vadiagem dos homens pobres e livres, o alistamento compulsório era o mecanismo utilizado pelas autoridades para esvaziar os espaços públicos dos desordeiros e desocupados. A rígida disciplina militar que incluía prisões, suspensão de soldos, castigos corporais e, principalmente, os baixos soldos justificam as constantes deserções e o horror que o alistamento compulsório provocava na população ${ }^{56}$. Por outro lado, o alistamento poderia ser a única opção de trabalho para os libertos ou forros que viam na carreira militar uma maneira de fugir ao trabalho manual, tão estigmatizado na sociedade escravocrata.

A fim de aumentar seus parcos vencimentos, muitos soldados usavam de diversos procedimentos que iam desde a contravenção até a criminalidade. Alguns se dedicavam ao roubo, assaltando transeuntes das ruas e estradas, sobretudo à noite. Outros se dedicavam ao comércio de bebidas no interior da cadeia, que constituía uma contravenção terminantemente proibida pelo artigo 165 do Regulamento $\mathrm{n}^{\circ} 120$ de 31 de janeiro de 1842. Além disso, no exercício de suas funções, muitas vezes, eles as abandonavam para freqüentarem as tavernas, embriagando-se, se envolvendo em brigas e desacatando seus superiores, tornando-se, deste modo, passíveis de punição severa. Nas horas de folga, outros tantos freqüentavam batuques e cateretês que, conforme vimos acima, eram duramente reprimidos.

Os comportamentos considerados indisciplinados de alguns soldados revelava uma posição ambígua deles em relação à aplicação da disciplina, da lei e da ordem no espaço urbano. Ao mesmo tempo, essas ações contribuíam para a elaboração do discurso desclassificatório das autoridades e das elites sobre a sua categoria profissional. Aqueles que diligentemente seguiam as ordens de seus superiores utilizavam a violência aberta, conforme já podemos constatar na repressão aos comportamentos da população civil que eram considerados irregulares.

A violência cometida pelos soldados contra as prostitutas e as mulheres embriagadas começava no momento em que eram interceptadas pelas patrulhas. Algumas delas eram agarradas pelos cabelos até o interior da Cadeia. Ali eram recolhidas no pior cômodo da prisão. O edifício, erguido no século XVIII, era 
considerado a melhor cadeia de toda a província. As dimensões da prisão destinada às mulheres eram 4,31m de altura, por 4,18m de comprimento e 3,93m de largura, possuindo a capacidade de abrigar, no máximo, oito detentas. Entretanto, a média de prisões de mulheres desordeiras se estendia entre três a cinco por noite, aumentando o número de encarceradas de onze a treze pessoas, constituindo uma superlotação em um ambiente de proporções modestas. Durante o dia, as mulheres passavam o dia na cozinha da cadeia, a qual estava localizada num quarto no fundo do quintal.

Na prisão, as mulheres poderiam ser vítimas do assédio sexual tanto por parte do carcereiro, quanto da guarda da prisão e dos próprios presos. Em 1845, Maria do Rosário, analfabeta, pediu a Romão Pereira Leite que escrevesse ao Chefe de Polícia, solicitando providências contra o carcereiro que a mantinha presa “nas algemas” por ela se recusar ter relações com ele. ${ }^{57}$ Igualmente em 1884, o carcereiro denunciou a seguinte irregularidade dentro da cadeia:

Tenho a honra de participar a V.Exa que notando indicios de gravidez na preza Maria Nunes d'Oliveira, interroguei a mesma sobre esse assumpto; respondeu-me ella que concebera na latrina d'esta cadêa, onde o cadete José do Espírito Santo, então praça simplis mancomunado com o prezo Saturnino Dias, obrigou-a a entrar para copular com o dito prezo, dizendo-a que elle cadete se responsabilizaria pela consequencia do irregular procedimento que tivera, e que esse facto deu-se quando o referido cadete fazia sentinela no patio da cadêa. 58

As constantes “desordens” causadas pelas prostitutas e outros elementos das camadas populares levaram os jornais vilaboenses a escreverem:

Mais policia, senhora policia!

A cerca de policia nesta terra vamos cada vez á peior; pode-se bem perguntar si ainda reside por aqui essa recatada senhora, pois tem vivido tão amoitada e tão subtil, que já ninguem se avista com ella.

Todo Goyaz sabe que prostitutas, morando no centro da cidade, em proximidade de casas de familia, estão a fazer chinfrins todas as noites com escandalo da moralidade publica, e offensa immediata aos visinhos; no em tanto que a senhora policia... cochila!.. Será preciso acreditar-se que ella anda de conivencia nos deboches das meretrizes?

Será preciso que os offendidos, em falta de melhores recursos, se vejão na dura necessidade de declinar nomes de pessôas que, durante o dia claro, andão de gravat'alta ao pescoço, e durante a noite não se pejam de fazerem conhecer as suas vozes e risadas em reuniões reprovadas pela moral e pela lei?

Não recuaremos diante desse extremo, si a continuação dos escandalos e da evangelica paciencia da senhora policia nos obrigarem á usarmos delle 59 .

Onde está a Policia? 
[...] Innumeros casos se dão constantemente: este queixa-se de que lhe roubarão, aquelle que foi espancado, outro que foi injuriado publicamente com palavras... E a polícia não apparece para ao menos tomar conhecimento dos factos! Onde estará ella?60

Em ambos os artigos aparecem reclamações contra a inércia da polícia na repressão das contravenções e dos crimes. Tais jornais eram de propriedade de grupos políticos de oposição ao governo local, portanto, argumentar sobre a ineficiência da corporação policial era o mesmo que atacar com severas críticas a administração provincial. Por outro lado, observamos, ao longo deste trabalho, que a polícia procurava reprimir qualquer contravenção às leis e aos costumes. Mas a questão é que o aparato repressivo da lei e do policiamento ostensivo só conseguia exercer uma das três funções da punição jurídica, qual seja, a de retribuir o castigo aos infratores. As outras duas funções da pena, reeducar os infratores e prevenir contra novas infrações, não foram atingidas ou muito pouco exercidas, haja vista os inúmeros casos de contravenções e reincidências, cujos registros encontram-se espalhados nos arquivos do Estado de Goiás.

A respeito da eficácia da punição jurídica, Durkheim escreveu “a pena não serve -ou só serve secundariamente - para corrigir o culpado ou para impedir seus possíveis imitadores; sob esse duplo ponto de vista sua eficácia é duvidosa e, de qualquer modo medíocre. Sua verdadeira função é manter intacta a coesão social”61. Em outras palavras, o castigo é destinado a agir mais sobre as pessoas honestas, cujo sentimento de solidariedade ele reforça, do que sobre os criminosos. A sanção pode ter certa eficácia dissuasiva; mas como o sentimento de aversão é fraco em certos indivíduos, não se pode supor que ela elimine o crime. A punição que o direito prescreve serve para legitimar os costumes, a moral, o Estado, a dominação de uma classe social sobre as outras.

Deste modo, Simmel assinala que o direito ou a lei constitui um conjunto de normas que tende a unificar os segmentos sociais ou pequenos grupos numa ordem jurídica uniforme; a moral refere-se a um padrão de conduta que o indivíduo impõe-se a si mesmo nas suas relações com os outros; enquanto os costumes são um conjunto de normas onde o direito e a lei não existem ou ainda existem de forma embrionária, ou ainda, são o conjunto de um pequeno grupo categoria ou segmento social 62 . Compreendemos assim, porque o discurso da lei usava de argumentos em defesa da moral e dos costumes, para melhor circunscrevê-los numa ordem e para legitimá-la. 
Contudo, “a vida quotidiana apresenta várias possibilidades, pois não é jamais unívoca”.63 Não existe na sociedade uma única ordem, mas uma ordem dominante coexistindo com várias outras ordens. Entretanto, essa ordem dominante tende a considerar as demais ordens como atípicas ou patogênicas, isto é, como desordens, para que sirvam de justificativa para uma ideologia, uma política centralizadora e saneadora. Nesse enfrentamento, a ordem estabelecida como dominante, continuamente desafiada pelas (des)ordens, estabelece uma correlação entre normalização e transgressão. A norma determina a demarcação de um centro e suas periferias. A transgressão da norma representa a negação desse centralismo, provocando um constante reordenamento da vida social em sua heterogeneidade.

A insubmissão das prostitutas da Cidade de Goiás, no século XIX, traduzia esse questionamento da ordem dominante, sendo representada como transgressão, provocando um reordenamento da vida cotidiana, ao mesmo tempo em que promovia a coesão social dos indivíduos e dos grupos sociais que se acomodavam ao discurso da lei.

\section{NOTAS}

* Danilo Rabelo é doutorando em História no Programa de Pós-Graduação em História da Universidade de Brasília, professor de sociologia CEPAE/UFG, pesquisador do CECAB (Centro de Estudos do Caribe no Brasil).

${ }^{1}$ Pierre Bordieu. Ce que parler veut dire. Paris: Fayard, 1982, p. 135.

${ }^{2}$ Roger Chartier. “O mundo como representação” in Estudos Avançados, no 11, v. 5, 1991.

${ }^{3}$ Cf. Regulamento n. ${ }^{\circ} 120$ de 31/01/1842 in Collecção das Leis do Imperio do Brazil de 1842, 3. ${ }^{\text {a ed., Rio }}$ de janeiro, Imprensa Nacional, 1906, art. 153 e 154.

${ }^{4}$ Fórum da Cidade de Goiás, Cartório de Crimes, Caixa 53,. Processo n. ${ }^{0}$ 2825, Infração de Termo de Bem Viver contra Maria Rufina da Penha, 1885.

${ }^{5}$ Laure Adler. A vida nos bordéis de França: 1830-1930. Lisboa, Terramar, 1990, p. 11

${ }^{6}$ Ibidem, p. 14.

${ }^{7}$ Maria Dulce Gaspar. Garotas de Programa: Prostituição em Copacabana e Identidade Social. Rio de Janeiro: Jorge Zahar Editor, 1985, p. 79.

8 Alain Corbin "Bastidores" in Michelle Perrot (org.) História da Vida Privada, 4 (Da Revolução Francesa à Primeira Guerra). 2a ed. São Paulo: Companhia das Letras, 1991, p. 539.

9 Santo Agostinho, De Ordine, Livro II, cap. IV, apud. Maria Dulce Gaspar. Garotas de Programa: Prostituição em Copacabana e Identidade Social. Rio de Janeiro: Jorge Zahar Editor, 1985, p. 67-68.

10 Alex J. B. Parent-Duchâtelet "De la prostitution dans la ville de Paris “, Paris, 1836, reed. Completa Paris, 1857, citado por Laure Adler, A vida nos bordés de França: 1830-1930, Trad. Maria da Assunção Santos, Lisboa, Terramar, 1990, p. 13. 
${ }^{11}$ Magali Engel. Meretrizes e doutores: saber médico e prostituição no Rio de Janeiro (1840-1890). São Paulo: Brasiliense, 1989, p. 140.

${ }^{12}$ Cf. Martha de Abreu Esteves, Meninas perdidas: os populares e o cotidiano do amor no Rio de janeiro da Belle Éoque, Rio de Janeiro, Paz e Terra, 1989; Joana Maria Pedro, Mulheres honestas e mulheres faladas: uma questão de classe, Florianópolis, Ed. UFSC, 1994 e Sidney Challhoub, Trabalho, lar e botequim: o cotidiano dos trabalhadores no Rio de janeiro da Belle Époque, São Paulo, Brasiliense, 1986.

${ }^{13}$ Correio Official, n. ${ }^{\circ} 41$ de 02/06/1877.

${ }^{14}$ Código Criminal do Império do Brazil (Lei de 16 de dezembro de 1830), Rio de Janeiro, Typographia Nacional, 1831.

15 “Código do Processo Criminal de Primeira Instância” in Collecção das Leis do Imperio do Brazil de 1832, Rio de Janeiro, Typographia Nacional, 1874.

16 “Regulamento n. ${ }^{\circ} 120$ de 31 de Janeiro de 1842” in Collecção das Leis do Império de 1842, 3. ${ }^{\text {a }}$ ed., Rio de Janeiro, Imprensa Nacional, 1906.

${ }^{17}$ Código Criminal do Imperio do Brazil, Rio de Janeiro, Typographia Nacional, 1831.

${ }^{18}$ Fórum da Cidade de Goiás, Cartório de Crimes, Caixa 53, Processo de Infração de Termo de Bem Viver contra Maria Escolastica, 1883.

${ }^{19}$ Código Criminal do Imperio do Brazil, Rio de Janeiro, Typographia Nacional, 1831.

${ }^{20}$ Fórum da Cidade de Goiás, Cartório de Crimes, Caixa 53, Processo de Infração de Termo de Bem Viver contra Maria Escolastica, 1884.

${ }^{21}$ Fórum da Cidade de Goiás, Cartório de Crimes, Caixa 53,. Processo n. ${ }^{\circ}$ 2825, Infração de Termo de Bem Viver contra Maria Rufina da Penha, 1885.

${ }^{22}$ AHEG, Documentos Avulsos, Caixa 296 - Polícia, 1880.

${ }^{23}$ Laure Adler. A vida nos bordéis de França: 1830-1930. Lisboa, Terramar, 1990, p. 184.

${ }^{24}$ Fórum da Cidade de Goiás, Cartório de Crimes, Caixa 53,. Processo n. ${ }^{\circ}$ 2825, Infração de Termo de Bem Viver contra Maria Rufina da Penha, 1885.

${ }^{25}$ Idem.

${ }^{26}$ Laure Adler. A vida nos bordéis de França: 1830-1930. Lisboa, Terramar, 1990, p. 10-12.

${ }^{27}$ AHEG, Documentos Avulsos, Caixa 173, Polícia, 1866.

${ }^{28}$ Maria Sylvia de Carvalho Franco. Homens Livres na Ordem Escravocrata. $3^{\text {a }}$ ed. São Paulo: Kairós, 1983, p. 50.

${ }^{29}$ Fórum da Cidade de Goi;ás, Cartório de Crimes, Caixa 15, Processo n. ${ }^{\circ} 2410$ contra Maria Sebastiana da Silva, 1870.

${ }^{30}$ Fórum da Cidade de Goiás, Cartório de Crimes. Caixa 15, Processo n. ${ }^{\circ} 2331$ contra Maria Cardoso dos Santos, 1870.

${ }^{31}$ Idem.

${ }^{32}$ Fórum da Cidade de Goiás, Cartório de Crimes, Caixa 13, Processo n. ${ }^{0} 2835$ contra Maria Luzia da Conceição, 1885.

${ }^{33}$ AHEG - Documentos Avulsos, Caixa 327 - Polícia, 1883.

${ }^{34}$ Michel Mafesoli. A Conquista do Presente. Rio de Janeiro: Rocco, 1984, p. 61-62.

${ }^{35}$ Roberto DaMatta. A casa \& a Rua: Espaço, Cidadania, Mulher e Morte no Brasil. Rio de Janeiro Guanabara, 1987, p. 11-29.

${ }^{36}$ A iluminação pública da Cidade de Goiás foi iniciada em 1849, cf. Memórias Goianas 4 Relatórios dos Governos da Província de Goiás 1845-1849. Goiânia: Ed. UCG, 1996, p. 168.

37 Posturas Policiais da Cidade de Goiás, Lei de 07 de fevereiro de 1831 in A Matutina Meiapontense (edição fac-símile). 
${ }^{38}$ Michelle Perrot. História da Vida Privada 4, (da Revolução Francesa à Primeira Guerra). $2^{\mathrm{a}}$ ed. São Paulo: Cia das Letras, 1991, p. 17.

${ }^{39}$ Michel Mafesoli. A Conquista do Presente. Rio de Janeiro: Rocco, 1984, p. 60.

${ }^{40}$ Margareth Rago. "Prazer e Perdição: a representação da cidade no anos vinte” in Revista Brasileira de História: Cultura \& Linguagens. São Paulo: ANPUH/Marco Zero, vol. 7, nº 13, set 1986-fev 1987, p. 87. Cf. também Claude-Gilbert Dubois, O Imaginário da Renascença. Trad. De Sérgio Bath, Brasília, Ed. UnB, 1995, p. 157 a 193).

${ }^{41}$ Michel Mafesoli. A Conquista do Presente. Rio de Janeiro: Rocco, 1984, p. 60-61.

${ }^{42}$ Correio Official n. 49 de 07/07/81.

${ }^{43}$ Voltarete: (de voltar), certo jogo de cartas entre três parceiros, com um baralho de quarenta cartas. Um dos acidentes desse jogo, que também se chama voltarete de respeito. In Dicionário Prático Ilustrado, Porto, Lello \& Irmão Editores, 1968.

${ }^{44}$ Solo: jogo de cartas. Uma das fases desse jogo. Idem.

${ }_{45}$ Trinta e quarenta e, trinta e um são jogos de carta; vermelhinha é conhecido como jogo fraudulento de cartas, Idem.

${ }^{46}$ AHEG, Caixa do Município de Goiás, n. ${ }^{\circ}$ 02, Ano de 1883.

${ }^{47}$ AHEG, Documentos Avulsos, Caixa n. ${ }^{\circ}$ 392, Polícia - 1889.

${ }^{48}$ Apud. Sérgio Paulo Rouanet (org.). O homem e o discurso: a arqueologia de Michel Foucault. Rio de Janeiro: Tempo Brasileiro, 1972, p. 152.

${ }^{49}$ AHEG, Documentos Avulsos, Caixas n. ${ }^{\circ} 248$ e 257, Polícia - 1875 e 1876 (respectivamente).

${ }^{50}$ Michel Mafesoli. A Conquista do Presente. Rio de Janeiro: Rocco, 1984, p. 53-62.

${ }^{51}$ Cf. Laure Adler, A vida nos bordés de França: 1830-1930, Trad. Maria da Assunção Santos, Lisboa, Terramar, 1990 e Magali Engels, Meretrizes e doutores: saber médico e prostituição no Rio de janeiro (1840-1890), São Paulo, Brasiliense, 1989.

52 Sobre a socialidade das meretrizes com soldados, marinheiros e outros segmentos sociais, cf. os contos de Guy Maupassant, "Bola de Sebo", "Mademoiselle Fifi” e "Pensão Tellier” in Bola de Sebo e outros contos, Rio de Janeiro, Globo, 1987; Aluízio de Azevedo, O Cortiço, São Paulo, Ática, s/d; Charles Baudelaire, Sobre a Modernidade, São Paulo, Paz e Terra, 1996, p. 44-46.

${ }^{53}$ AHEG, Documentos Avulsos, Caixa 145, Polícia, 1862.

${ }^{54}$ AHEG, Documentos Avulsos, Caixa 327, Polícia, 1883.

${ }^{55}$ AHEG, Documentos Avulsos, Caixa 197, Polícia, 1870.

${ }^{56}$ Rabelo, Danilo. “Os excessos do corpo: a normatização dos comportamentos na Cidade de Goiás, 18221889”. Goiânia: UFG/FCHF, 1997, p. 175-180. (dissertação de mestrado).

${ }^{57}$ AHEG, Documentos Avulsos, Caixa 045, Polícia, 1845.

${ }^{58}$ AHEG, Documentos Avulsos, Caixa 334, Polícia, 1884.

${ }^{59}$ Província de Goyaz, n. ${ }^{\circ}$ 40, 30 de setembro de 1870.

${ }^{60}$ Tribuna Livre, . $^{\circ}$ 67, 31 de maio de 1879.

${ }^{61}$ Émile Durkheim. De la division du travail social. $7^{\text {a }}$ ed. Paris: Presses Universitaires de France, 1960, p. 73-78.

${ }^{62}$ Georg Simmel. Sociologia. (org. Evaristo de Moraes Filho). São Paulo: Ática, 1983, p. 101-106.

${ }^{63}$ Michel Mafesoli. O conhecimento do Cotidiano. Lisboa: Veja, s/d, p. 47.

\section{FONTES}




\section{FONTES MANUSCRITAS}

Arquivo Histórico Estadual de Goiás (AHEG)

Coleção Documentos Avulsos - Assunto: Polícia

$\begin{array}{ll}\text { Caixas } & \text { Ano } \\ 045 & 1845 \\ 145 & 1862 \\ 173 & 1866 \\ 197 & 1870 \\ 248 & 1875 \\ 257 & 1876\end{array}$

BRASIL. "Regulamento n. ${ }^{\circ} 120$ de 31 de Janeiro de 1842" in Collecção das Leis do Império de 1842, 3. ${ }^{a}$ ed., Rio de Janeiro, Imprensa Nacional, 1906.

\section{REFERÊNCIAS BIBLIOGRÁFICAS}

ADLER, Laure. A vida nos bordés de França: 1830-1930, Trad. Maria da Assunção Santos, Lisboa, Terramar, 1990, p. 13.

AZEVEDO, Aloísio de. O Cortiço, 13. ${ }^{\text {a }}$ ed. São Paulo: Ática, 1983.

BAUDELAIRE, Charles. Sobre a Modernidade: o pintor da vida moderna. (org. Teixeira Coelho). Rio de Janeiro: Paz e Terra, 1996 (Coleção Leitura).

BOURDIEU, Pierre. Ce que parler veut dire. Paris: Fayard, 1982.

CALHOUB, Sidney. Trabalho, lar e botequim: o cotidiano dos trabalhadores no Rio de Janeiro da BelleH Époque, São Paulo, Brasiliense, 1986.

CHARTIER, Roger. “O mundo como representação” in Estudos Avançados, n. . 11, v. 5, 1991.

CORBIN, Alain. "Bastidores" in PERROT, Michelle (org). História da Vida Privada, 4 (Da Revolução Francesa à Primeira Guerra). (trad. Denise Bottman e Bernardo Joffily), 2. ${ }^{\text {a }}$ ed. São Paulo: Companhia das Letras, 1991, p. 413-611.

DA MATTA, Roberto. A Casa \& a Rua: Espaço, Cidadania, Mulher e Morte no Brasil. Rio de Janeiro: Guanabara, 1987.

DUBOIS, Claude-Gilbert. O Imaginário da Renascença. (Trad. De Sérgio Bath), Brasília, Ed. UnB, 1995, p. 157 a 193).

DURKHEIM, Émile. De la division du travail social. 7. ${ }^{a}$ ed. Paris: Presses Universitaires de France, 1960.

ENGEL, Magali. Meretrizes e doutores: saber médico e prostituição no Rio de janeiro (1840-1890), São Paulo, Brasiliense, 1989.

ESTEVES, Martha de Abreu. Meninas perdidas: os populares e o cotidiano do amor no Rio de janeiro da Belle Éoque, Rio de Janeiro, Paz e Terra, 1989.

FOUCAULT, Michel. Microfísica do Poder. (org. e trad. Roberto Machado). 11. ${ }^{\text {a }}$ ed. Rio de Janeiro: Graal, 1993.

FRANCO, Maria Sylvia de Carvalho. Homens Livres na Ordem Escravocrata. 3. ${ }^{a}$ ed., São Paulo: Kairós, 1983.

GASPAR, Maria Dulce. Garotas de Programa: Prostituição em Copacabana e Identidade Social. Rio de Janeiro: Jorge Zahar Editor, 1985.

MAFESOLI, Michel. O Conhecimento do Quotidiano. Lisboa: Veja, s/d. 
A Conquista do Presente. Rio de Janeiro: Rocco, 1984, p. 52-62.

MAUPASSANT, Guy de. Bola de Sebo e outros contos. (trad. Mário Quintana, Cassimiro Fernandes, Justino Martins). Rio de Janeiro: Globo, 1987.

MÉRIMÉE, Prosper. Cármen e outras novelas. (trad. Mário Quintana) Rio de Janeiro: Globo, 1987.

PEDRO, Joana Maria. Mulheres honestas e mulheres faladas: uma questão de classe,Florianópolis, Ed. UFSC, 1994.

PERROT, Michelle (org). História da Vida Privada, 4 (Da Revolução Francesa à Primeira Guerra). (trad. Denise Bottman e Bernardo Joffily), 2. a ed. São Paulo: Companhia das Letras, 1991.

RABELO, Danilo. “Os Excessos do Corpo: a normatização dos comportamentos na Cidade de Goiás, 1822-1889”, Goiânia: FFCH/UFG, 1997 (Dissertação, mestrado em História).

RAGO, Margareth. "Prazer e Perdição: a representação da cidade nos anos vinte” in Revista Brasileira de História: Cultura \& Linguagens, São Paulo: ANPUH/Marco Zero, vol. 7, n. ${ }^{0}$ 13, p. 77-102, set, 1986/fev, 1987.

ROUANET, Sérgio Paulo (org). O homem e o discurso; a arqueologia de Michel Foucault. Rio de Janeiro: Tempo Brasileiro, 1972. (Comunicação/3).

SIMMEL, Georg. Sociologia. (org. Evaristo de Moraes Filho; trad. Carlos Alberto Pavanelli et al.). São Paulo: Ática, 1983. 